\section{The Future of Life}

\author{
by E.O. Wilson \\ Alfred A. Knopf, 229 pp, \$22.00, 2002
}

\section{Reviewed by Russell F. DoOltTtle Center for Molecular Genetics \\ University of California, San Diego La Jolla, California, USA}

E.O. Wilson is among America's most eminent biologists. Winner of two Pulitzer prizes and the recipient of countless scientific honors, his influence extends far beyond the scientific community. In this well documented if somewhat mistitled book, he chronicles the sad destruction of the planet Earth by the human species. Hammering home the theme he makes so well in his public lectures, he reminds the reader that for the rest of the current world's population to be raised to the U.S. level of consumption would require four more planet Earths.

The Future of Life has only seven chapters, the first six of which are beautifully written essays;

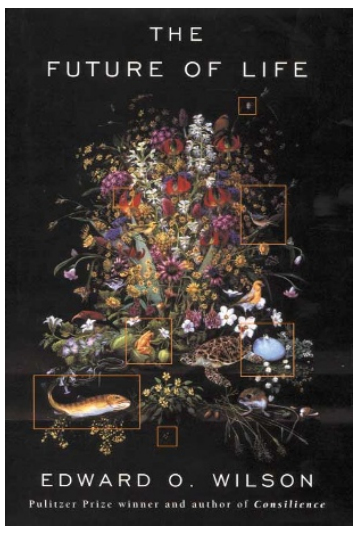
each could easily stand alone and be read profitably by any literate citizen. In a charming prologue, Wilson pens a letter to Henry David Thoreau-a pioneer of the conservation movementtelling him not only about the present condition of Walden Pond but also about the state of the world: that there are now more than six billion people, the great majority of whom are poor, and a billion on the edge of starvation-equivalent to the world's entire population in 1800 .

The first six chapters state the facts: the extent of biodiversity, how human beings evolved to be plunderers, how environmental incursions occur, the worldwide demise of large animals, the rapidly accelerating loss of species. Wilson, a gifted and forceful writer, spares no society, from the Aboriginals of Australia to the Maoris of New Zealand to the European settlers of the New World. But the major aggravation, he notes, is that in the twentieth century the pattern of human population growth "was more bacterial than primate," heading for a likely world popu- lation of more than 10 billion by the middle of this century. Adding to the woe is the growing disparity between the haves and have-nots of the world.

China in particular receives a good deal of deserved scrutiny. Today, the 1.2 billion Chinese account for one in every five persons on Earth. (Wilson missed a chance to point out that were it not for China's much maligned "one-child policy," one in every four persons on Earth today could have been Chinese.) China's problems seem overwhelming, whether it be the availability of water or the limits of world grain production and what Chinese demand will do to prices in less developed countries. That Chinese folk medicine is coupled to the demise of exotic rhinoceri (because of the alleged medicinal powers of horn extracts) only seems to rub salt in an already mortal wound.

Given this hopelessly depressing state of affairs, I desperately looked forward to the last chapter, titled 'The Solutions'. Alas, I was greatly disappointed. It's as though the author had forgotten every-

implied parity is unrealistic. The "juggernaut of technology-based capitalism will not be stopped," he concedes. So where does he glean his "cautious optimism"? So long as we have an economic system that depends absolutely on growth, there are no grounds for even cautious optimism.

Wilson offers a specific 12-point plan for saving a slice of the world's ecosystems, mainly through concentrating on high-yield targets. 25 hotspots around the world account for only 1.4 percent of the Earth's land mass, he reasons, but are the last remaining habitat for $40 \%$ of vascular plants and non-fish vertebrates. He estimates that saving these targets could be financed by as little as a one-centper-cup tax on coffee.

Much of Wilson's strategy for turning matters around depends on wilderness buy-backs and zoo breeding programs. He touts a proposal to turn the Demilitarized Zone between North and South Korea into a habitat for biodiversity. Certainly no biologist would oppose these worthy if modest goals. But can they save the world? We will be saved, Wilson says, because we now understand the problem.

A more accurate title for this book would have been "The Threatened Future of Biodiversity". A cynic might even have argued for the longer title: "If We Can't Save the Planet, Let Us Please Keep a Little Slice of It Naturally Diverse for the Little While We Have Left".

\section{Envisioning Science: The Design and Craft of the Scientific Image} will not be any humans at all in the future.

Wilson's message is one of compromise. Science, he says, must join with religion in pursuing a future course. This implies an undeserved equity. In my view, such a coalition will never be effective until the leaders of the world's major religions acknowledge the arithmetic of human reproduction and the need for a population decline. Similarly, Wilson proposes an equilateral triangle of cooperation among the Private Sector, Government, and Science and Technology to address biodiversity problems. Once again, the

\section{by Felice Frankel \\ MIT Press, \$55.00, 320 pp, 2002
Reviewed by Philip Hockberger Department of Physiology Northwestern University Chicago, Illinois, USA

Award-winning science photographer Felice Frankel has compiled some of her favorite images into this how-to book aimed at showing both novice and experienced scientists how to make memorable images of their work. She shares her secrets for photograph- 